\title{
Losy sióstr Habsburżanek Katarzyny, Barbary i Joanny po śmierci ojca, cesarza Ferdynanda I w świetle korespondencji rodzinnej
}

Ferdynand Habsburg, syn Joanny Szalonej i Filipa I Pięknego, cesarz w latach 1556 - 1564 i Anna Jagiellonka, córka Władysława II, króla Czech i Węgier oraz Anny de Foix, doczekali się licznego potomstwa. Spośród piętnaściorga dzieci aż trzynaścioro dożyło wieku dorosłego. Przeważała płeć piękna - Ferdynand i Anna mieli dziesięć córek. Pomimo swojego przywiązania do synów (szczególnie do arcyksięcia Ferdynanda), Ferdynand ojciec z wielką radością witał na świecie córki. Uważał, że to właśnie one przyczyniają się do budowania więzów powinowactwa ${ }^{1}$. W myśl polityki dynastycznej doceniał ich wartość jako przyszłych małżonek władców europejskich, z którymi mógłby zawierać różnego rodzaju sojusze ${ }^{2}$. Z dziesięciu córek aż siedem zostało wydanych za mąż. Najstarsza z nich, Elżbieta w 1543 roku zawarła związek małżeński z królem Polski i wielkim księciem litewskim Zygmuntem Augustem. Małżeństwo to nie trwało długo, gdyż młoda Habsburżanka wkrótce zmarła. Arcyksiężniczki były wydawane za mąż do Polski (dwukrotnie), Bawarii (dwukrotnie) oraz do krajów włoskich: Mantui, Ferrary i Toskanii (czterokrotnie) $)^{3}$.

Podstawę źródłową niniejszego artykułu stanowi korespondencja cesarza Maksymiliana II z jego bratem Ferdynandem Tyrolskim z lat 1564 - 1567. Są to oryginalne niemieckojęzyczne teksty opublikowane przez Veröffentlichungen der Kommission für neuere Geschichte Österreichs. Zbiór został wydany w dwóch tomach w 1916 i 1921 roku. Prócz wymiany korespondencji cesarza z Ferdynandem Tyrolskim, można tam odnaleźć pisma arcyksięcia Karola (brata cesarza Maksymiliana II), Albrechta Bawarskiego (szwagra cesarza), czy Zygmunta Augusta i Filipa II Hiszpańskiego. W polskiej historiografii listy te były w niewielkim stopniu wykorzystane, a stanowią cenne źródło informacji na temat relacji

1 S. Grodziski, Habsburgowie. Dzieje dynastii, Wrocław 1998, s. 69.

2 J. Besala, Matżeństwa królewskie. Jagiellonowie, Warszawa 2006, s. 194.

3 R. Reifenscheid, Die Habsburger. Von Rudolf I bis Karl I, Wien 1994, s. 129-133. 
rodzinnych dynastii Habsburgów. Na ich podstawie można poznać niektóre problemy, z jakimi musieli się zmagać członkowie rodziny cesarskiej.

Celem artykułu jest przedstawienie losów trzech sióstr Maksymiliana II i Ferdynanda Tyrolskiego, a mianowicie arcyksiężniczek Katarzyny, Barbary i Joanny po śmierci ich ojca cesarza Ferdynanda I. To właśnie związane z nimi kwestie są jednym $\mathrm{z}$ tematów poruszanych w korespondencji braci.

$\mathrm{Z}$ perspektywy podejmowanego $\mathrm{w}$ artykule tematu wykorzystane $\mathrm{w}$ nim źródła można uznać za wiarygodne. Po śmierci cesarza Ferdynanda I na Maksymiliana i Ferdynanda Tyrolskiego spadał obowiązek opieki nad siostrami. Jedną z powinności braci wobec nich było wydanie ich za mąż, oczywiście z korzyścią dla dynastii. Ponadto, musieli dbać o interesy zamężnych już sióstr, jak to miało miejsce w przypadku arcyksiężniczki Katarzyny. Konsultacje i dyskusje na temat spraw z nimi związanych były zatem czymś naturalnym, wchodzącym w kanon problemów rodzinnych. Należy jednak pamiętać, że korespondencja ta daje obraz jednostronny. Pozwala poznać jeden $\mathrm{z}$ aspektów spraw rodzinnych istotnych dla dynastii habsburskiej.

W kwestii małżeństwa arcyksiężniczki Katarzyny z Zygmuntem Augustem, prócz korespondencji, dodatkowo zostały wykorzystane polskie źródła, a mianowicie Kronika Polska Marcina Bielskiego oraz Dzieje w Koronie Polskiej Lukasza Górnickiego. Kroniki te pozwalają spojrzeć na problem związku z królem polskim z perspektywy tego, co się działo w Rzeczypospolitej. Trzeba jednak zauważyć, że informacje w nich zawarte mogą mieć charakter subiektywnej interpretacji i oceny opisywanych wydarzeń.

Najstarsza z wymienionych sióstr, Katarzyna, urodziła się w 1533 roku w Wiedniu. Już jako mała dziewczynka została wysłana do Innsbrucka. W ramach polityki dynastycznej Habsburgów była przeznaczona do stanu małżeńskiego. Jako szesnastoletnia dziewczyna wyszła za mąż za księcia Mantui Franciszka III Gonzagę. Ślub odbył się 27 października 1549 roku. Choć mąż Katarzyny był jej rówieśnikiem, małżeństwo nie trwało długo, ponieważ książę Mantui zmarł 21 lutego roku następnego ${ }^{4}$.

Kolejne małżeństwo Habsburżanki z Zygmuntem Augustem było oczywiście zaaranżowane i miłość nie odgrywała tu żadnej roli. Wielka miłość króla polskiego, Barbara Radziwiłłówna zmarła w 1551 roku. Ich małżeństwo nie było akceptowane zarówno wśród szlachty, jak i wśród elit możnowładczych. Jego zagorzałą przeciwniczką była królowa Bona. Związek z Barbarą trwał krótko i dość szybko po jej śmierci zaczęto namawiać króla, by ponownie się ożenił. Wśród kandydatek na nową królową wymieniana była tym razem siostra króla Francji, Małgorzata ${ }^{5}$, a także księżniczka bawarska i księżna Ferrary oraz właśnie

4 R. Żelewski, Katarzyna Austriaczka, [w:] Polski Stownik Biograficzny, t. 12, 1990, s. 214.

5 S. Cynarski, Zygmunt August, Wrocław 1988, s. 61. 
Katarzyna, arcyksiężniczka austriacka. Zygmunt August nie był przychylnie nastawiony do wizji nowego małżeństwa, tym bardziej, że te propozycje pojawiły się w tak krótkim czasie od śmierci Barbary ${ }^{6}$.

Ostatecznie Zygmunt August zdecydował się na zawarcie kolejnego związku małżeńskiego. Na jego decyzji zaważyły sprawy polityczne i dynastyczne. Król ponoć bardziej przychylał się do ożenku z księżniczką Ferrary, ale sprawy przybrały inny obrót, gdy na jaw wyszły konszachty Habsburgów z Iwanem IV Groźnym. Chodziło przede wszystkim o mediacje dyplomatyczne związane w ewentualną koronacją Iwana na cara w zamian za połączenie się z Kościołem katolic$\mathrm{kim}^{7}$. Habsburgowie ze swej strony liczyli na wpływ Zygmunta na jego siostrę Izabelę w sprawie Siedmiogrodu. Pod koniec lat czterdziestych zawarli z Zygmuntem Augustem umowę, w której król Polski zobowiązał się, że nie będzie ingerował w sprawy na Węgrzech. W 1552 roku Izabela wraz z synem wróciła do Polski ${ }^{9}$. Rzecznikiem małżeństwa króla polskiego z Habsburżanką był jego bliski współpracownik, brat stryjeczny Barbary, Mikołaj „Czarny” Radziwiłł, który został wysłany do Austrii w sprawie moskiewskiej. Jednocześnie rozpoczął starania o rękę Katarzyny dla Zygmunta Augusta. Z perspektywy problemów z Moskwą było to posunięcie bardzo korzystne, ponieważ Karol V i Ferdynand odstąpili od zawierania układów z wielkim księciem moskiewskim ${ }^{10}$. Radziwiłł przebywający w Wiedniu „(...) widząc wdowę księżnę mantuańską panią osobliwą i słysząc o wielkich jej cnotach i świętych obyczajach, dał znać królowi, iż podług jego zdania, godną być ją rozumie korony i łoża królewskiego" ${ }^{11}$. Wojewoda, chcąc przekonać Zygmunta Augusta starał się przedstawić Katarzynę w jak najlepszym świetle. Prawdopodobnie nie wiedział zbyt wiele o jej stanie zdrowia, gdyż ewentualne przypadłości przyszłej królowej musiały być skrzętnie ukrywane.

Do zawarcia małżeństwa potrzebna była dyspensa papieska. Tak o tej sprawie pisze Łukasz Górnicki: „Posłano też i do papieża, ponieważ pierwsza królewska żona, Elżbieta, rodzona była siostra księżny mantuańskiej, iżby bez popełnienia grzechu mógł ją mieć król za żonę; jakoż uproszono to u papieża"12. Dyspensa, o której tu mowa została uzyskana w maju 1553 roku $^{13}$. Ceremonia ślubna od-

6 A. Sucheni-Grabowska, Zygmunt August. Król polski i wielki książę litewski 1520-1562, Kraków 2010, s. 416.

7 S. Cynarski, op. cit., s. 61.

8 J. Szujski, Opowiadania i roztrzq̨ania, t. 2, Kraków 1886, s. 255. Zob.: G. Palffy, The kingdom of Hungary and the Habsburg monarchy in the sixteenth century, New York 2009.

9 S. Gołębiowski, Czasy Zygmunta Augusta. Ustęp z przeszłości, cz. 1, Wilno 1851, s. 115-116.

10 A. Sucheni-Grabowska, op. cit., s. 418-419.

11 Ł. Górnicki, Dzieje w Koronie Polskiej, Wrocław 1950, s. 52.

12 Ibidem, s. 53.

13 R. Żelewski, op. cit., s. 214. 
była się 29 lipca 1553 roku w Krakowie. Uroczystości weselne były przygotowane z wielkim rozmachem. Zygmunt August wysłał nawet zaproszenie do cesarza, który jednak się nie pojawił, lecz przysłał do Krakowa swoich posłów ${ }^{14}$. Panna młoda przybyła do stolicy Korony wraz z wielkim orszakiem ${ }^{15}$. Mieli jej towarzyszyć bracia Maksymilian i Ferdynand. Ten pierwszy nie dotarł wraz z siostrą na jej ślub, gdyż z powodu choroby musiał zostać w Ołomuńcu ${ }^{16}$. Tak przybycie młodej Habsburżanki przedstawia Marcin Bielski:

Królową Katarzynę do Polski na S. Ian przywieźli. A Król też Seym na ten czas dla Koronacyi iey w Krakowie złożywszy, sam ku czasowi z Litwy nieomieszkał przyjechać. Katarzynę brat Ferdynand przyprowadził, mając przy sobie posły oycowskie, y ludzi niemało zacnych Niemieckiego y Cesarskiego Narodu (... $)^{17}$.

W Rzeczypospolitej bardziej oczekiwano, że wraz Katarzyną w Krakowie pojawi się przyszły cesarz Maksymilian, więc niezbyt przychylnym okiem patrzono na arcyksięcia Ferdynanda. Z nim też wiąże się historia mówiąca o tym, jak w trakcie wesela siostry, będący pod wpływem alkoholu arcyksiążę zalecał się do Katarzyny Jagiellonki. Ponadto sugerował, że Zygmunt August nie będzie miał dzieci, jakby wiedział, że arcyksiężniczka nie będzie mogła mu ich dać. Namawiał króla, aby w przypadku bezpotomnej śmierci przekazał koronę polską Habsburgom. Powstała w wyniku tego sytuacja była niezwykle niezręczna, gdyż obecni na uroczystościach senatorowie odpowiedzieli mu, iż król nie ma wpływu na wybór swojego następcy, co było dla Zygmunta Augusta upokorzeniem ${ }^{18}$.

Należy zauważyć, że ślub Zygmunta Augusta z młodą Habsburżanką został dużo lepiej przyjęty niż poprzedni z Barbarą Radziwiłłówną ${ }^{19}$. Wiadomo było, że od Katarzyny oczekiwano przede wszystkim wydania na świat następcy tronu. Była to bardzo istotna kwestia, zwłaszcza dla króla, który po dwóch krótkich małżeństwach nie miał potomka. Nadzieja pojawiła się wiosną 1554 roku, kiedy Katarzyna oświadczyła, że jest w ciąży. Potwierdził to nawet badający ją lekarz. Po paru miesiącach okazało się, że była to fałszywa wiadomość. Po tym wydarzeniu pojawiły się negatywne komentarze o królowej. Mówiono nawet, że chciała upozorować ciążę, by móc podstawić Zygmuntowi obce dziecko. Mimo to para żyła ze sobą jeszcze około czterech lat. Rozpad małżeństwa rozpoczął się po ich powrocie z Wilna do Krakowa w 1558 roku $^{20}$. Widywali się coraz

14 A. Przeździecki, Jagiellonki polskie. Obrazy dworu Zygmunta I i Zygmunta Augusta Królów Polskich, t. 2, Kraków 1868, s. 25.

15 S. Cynarski, op. cit., s. 63.

16 A. Przeździecki, op. cit., s. 26.

17 M. Bielski, Kronika Polska, Warszawa 1764, s. 541.

18 J. Besala, op. cit., s. 255.

19 A. Sucheni-Grabowska, op. cit., s. 420.

20 S. Cynarski, op. cit., s. 66. 
rzadziej, a król nabierał coraz większej niechęci do małżonki. Prócz tego, że nie mogła dać mu potomka, nie podobały mu się próby Katarzyny mieszania się w politykę. Zygmunt August starał się odsuwać ją od kwestii państwa, ponieważ było wiadome, że Habsburgowie widzieli w niej swojego agenta, o czym świadczy rozległa korespondencja $\mathrm{z}$ ojcem, braćmi i posłami austriackimi ${ }^{21}$.

Już w 1559 roku Zygmunt August rozważał możliwość rozwodu z Katarzyną. W tym okresie królowa ciężko chorowała. W tym samym roku, na sejmie w Piotrkowie król podjął sprawę następstwa tronu, bo nadzieje na potomka były coraz mniejsze. Wysunął propozycję, by następca został wyznaczony za jego życia ${ }^{22}$. Dla Habsburgów wydarzenia w Polsce przybrały niekorzystny obrót, ponieważ groziło to utratą jakichkolwiek wpływów. Katarzyna była bowiem zamieszana w sprawy węgierskie. Działając na rzecz ojca próbowała odwieść Izabelę od jej wyjazdu z synem do Siedmiogrodu. Ostatecznie namowy nie przyniosły rezultatu, bo szwagierka jej opuściła Koronę w 1556 roku $^{23}$.

Swoją decyzję o rozstaniu z Habsburżanką Zygmunt August argumentował chorobą Katarzyny, a także bliskim jej pokrewieństwem z jego zmarłą żoną, choć należy pamiętać, że uzyskana została dyspensa papieska. Od rozstania z żoną próbował odwieść króla m.in. legat papieski Jan Franciszek Commendone. Ostateczne rozejście się dróg małżonków datuje się na 1563 rok, kiedy na czas trwania Sejmu piotrkowskiego Zygmunt umieścił małżonkę w Radomiu ${ }^{24}$. O rozkładzie pożycia małżeńskiego Katarzyna doniosła oczywiście braciom. Arcyksiążę Ferdynand radził cesarzowi, aby rozwiązać tę sprawę polubownie ${ }^{25}$. W 1564 roku miała miejsce intensywna wymiana poselstw, która okazała się jednak mało skuteczna ${ }^{26}$. Na początku 1565 roku cesarz Maksymilian II postanowił wysłać do Polski Christofa von Carlowitza, zapewne w nadziei, że uda mu się zdziałać więcej niż poprzedniemu poselstwu. W liście z 24 stycznia pisze o tym do arcyksięcia Ferdynanda prosząc go, aby nakłonił wspomnianego posła do przyjęcia tej trudnej i zarazem delikatnej misji ${ }^{27}$. Habsburgowie mieli dużą pomoc ze strony legata papieskiego Jana Franciszka Commendone, któremu, co prawda, nie udało się przekonać króla do zmiany decyzji, lecz wpłynął na postawę prymasa Jakuba Uchańskiego. To on początkowo był jednym z tych, którzy namawiali Zygmunta

21 U. Borkowska, Dynastia Jagiellonów w Polsce, Warszawa 2011, s. 544.

22 J. Szujski, op. cit., s. 276-277.

23 A. Sucheni-Grabowska, op. cit., s. 439-440.

24 S. Cynarski, op. cit., s. 190.

25 J. Szujski, op. cit., s. 278-279.

26 R. Żelewski, op. cit., s. 214.

27 Maximilian an Ferdinand aus Wien, 24. Jänner 1565, Korrespondenzen Österreichischer Herrscher. Korrespondenz Maximilians II., Band 1: Familienkorrespondenz 1564 Juli 26 bis 1566 August 11, [w:] Veröffentlichungen der Kommission für Neuere Geschichte Österreichs, Band 14, bearb. von V. Bibl, Wien 1916, s. 80. 
Augusta do rozpoczęcia starań o uzyskanie rozwodu ${ }^{28}$. Carlowitz z całą pewnością podjął się tego zadania, ponieważ w kolejnym liście Maksymiliana do Ferdynanda ponownie zostaje poruszona sprawa polskiej królowej. Jak donosi cesarz, brak jest jeszcze wiadomości od posła. W tym czasie odbywał się w Polsce Sejm. Cesarz prosi brata, gdyby Carlowitz nic na nim w ich sprawie nie „wskórał”, aby sam nie podejmował żadnych kroków ${ }^{29}$. Sejm, o którym mowa w liście, rozpoczął się 18 stycznia 1565 roku w Piotrkowie ${ }^{30}$. Dla Maksymiliana informacje z Polski były bardzo potrzebne, ponieważ na tych obradach podniesiona została sprawa królowej. Katarzyna, która jeszcze na początku lat sześćdziesiątych chciała utrzymania związku, teraz była gotowa wyjechać z tym zastrzeżeniem, żeby nie uznawać jej winy w rozpadzie małżeństwa. Opuszczenie przez nią Korony, prócz utraty wpływów, było dla Habsburgów równoznaczne ze stratą szansy na przejęcie polskiego tronu po śmierci Zygmunta Augusta. Posłowie cesarscy walcząc o utrzymanie Habsburżanki w kraju zgadzali się tylko na czasowy wyjazd w związku z pogrzebem ojca ${ }^{31}$. Kontakty między cesarzem a jego posłami były dość intensywne, o czym świadczy kolejny list do Ferdynanda. Donosi w nim o otrzymanych raportach z Polski, które pojawiły się w krótkim odstępie czasu. Czego one dotyczyły, nie wiadomo. Jak istotne było to dla Maksymiliana pokazuje jego prośba, by o stanie pertraktacji był regularnie informowany ${ }^{32}$.

Dążenie Zygmunta Augusta do rozwodu było dla Habsburgów nie do przyjęcia. Z perspektywy dynastii rakuskiej sprawa ta nie była korzystna przede wszystkim z przyczyn politycznych. Pewną rolę odgrywały względy religijne, choć były to zapewne kwestie drugorzędne. A jednak w maju 1565 roku Ferdynand w liście do Maksymiliana popiera decyzję brata o zgodzie na wyjazd królowej Katarzyny. Wyrażając nadzieję, że Zygmunt August się opamięta potwierdził tylko, iż dla Habsburgów jej odjazd był tylko tymczasowy ${ }^{33}$. W liście do braci Ferdynanda i Karola z 18 sierpnia Maksymilian donosi, że decyzja o wyjeździe ich siostry została zatwierdzona ${ }^{34}$. Katarzyna nie wyjechała z Polski tak szybko, jak oczekiwał król. Przekonany przez legata papieskiego Jakub Uchański robił wszystko,

28 S. Cynarski, op. cit., s. 193. Wpływ Jana Franciszka Commendone na Episkopat Polski nie ograniczał się tylko do kwestii związanych z małżeństwem króla. Jego celem było także umocnienie w Rzeczypospolitej stronnictwa katolickiego, które hamowałoby rozwój reformacji wśród elit. Zob. W. Zakrzewski, Po ucieczce Henryka. Dzieje bezkrólewia 1574-1575, Kraków 1878, s. 38.

29 Maximilian an Ferdinand aus Wien, 13. Februar 1565, Band 1, s. 101.

30 J. Szujski, op. cit., s. 282.

31 R. Żelewski, op. cit., s. 215.

32 Maximilian an Ferdinand aus Wien. 14. April 1565, Band 1, s. 147.

33 Ferdinand an Maximilian aus Prag, 19. Mai 1565, ibidem, Band 1, s. 161-162.

34 Maximilian an Ferdinand und Karl aus Wien, 18. August 1565, ibidem, Band 1, s. 247-248. 
by zatrzymać ją w kraju. Ostatnią próbę podjęto podczas Sejmu w Lublinie w 1566 roku. Tak tę sytuację w swojej kronice opisuje Marcin Bielski:

Stądże przyszło do tego, że jednego dnia gdy Król do Rady przyszedł, Uchański Arcybiskup z stołka powstawszy do Króla rzecz stojąc czynił, (z którym wszystka Rada powitała) napominając go, aby żoną swą nie gardził, a oney od siebie nieodsyłał: przypominając mu przysięgę, i ślub iego: przywodząc przykłady i karania od Boga za grzech: a na koniec y dla Boga go prosząc, aby się nad stanem swym Królewskim, sławą i sumieniem, i nad wszystko Rzecząpospolitą zmiłował, i tego domawiając ukląkł z płaczem, a na twarz swą padł, zaczym płacz się wszystkim z oczu rzucił.

Jak donosi dalej Bielski, napomnienia na niewiele się przydały, ponieważ Zygmunt August nie zmienił swojego zdania i dalej obstawał przy odesłaniu Katarzyny do Austrii ${ }^{35}$. Ostatecznie opuściła Polskę 8 października 1566 roku. Sprawa jej małżeństwa z królem Polski nie została rozstrzygnięta na forum międzynarodowym, a Zygmunt August nie uzyskał zgody na rozwód ${ }^{36}$, co definitywnie przekreśliło możliwość posiadania prawowitego następcy tronu.

W dalszej korespondencji Maksymiliana i Ferdynanda odnajdujemy jeszcze dwa listy poruszające temat królowej polskiej. W napisanym pod koniec grudnia liście najistotniejsza do odnotowania jest prośba cesarza o złożenie datków na utrzymanie ich siostry ${ }^{37}$. Przy trwających w tym okresie działaniach wojennych na Węgrzech, wyłożenie kolejnych pieniędzy musiało się wiązać z wielkim wysiłkiem finansowym. W odpowiedzi Ferdynand zgadza się udzielić pomocy bratu, i wraz z arcyksięciem Karolem będą łożyć na utrzymanie nieszczęśliwej siostry Katarzyny. W liście napisano: Die underhaltungen belanget soll es [meines thails] neben E. M., unangesehen meiner vorhin obligenden beschwerden (...) [Utrzymanie powinno się też tyczyć mojej części obok Waszej Cesarskiej Mości, bez względu na niedawno ciążące na mnie trudności (...) - tł. M. S. $]^{38}$.

Stan zdrowia Katarzyny pogarszał się po powrocie do Austrii. Jeszcze w 1567 roku posłowie cesarscy próbowali coś zdziałać w sprawie jej powrotu do Rzeczypospolitej, jednak starania te spełzły na niczym. Ostatecznie królowa osiadła na zamku w Linzu, gdzie 28 lutego 1572 roku zmarła. Jej życzeniem

\footnotetext{
35 M. Bielski, op. cit., s. 564. Po opuszczeniu przez Katarzynę Rzeczypospolitej Zygmunt August co roku wypłacał jej 20 tysięcy florenów na poczet utrzymania jej dworu. Zob. U. Borkowska, op. cit., s. 545.

36 R. Żelewski, op. cit., s. 216.

37 Maximilian an Ferdinand aus Wien, 28. Dezember 1566, Korrespondenzen Österreichischer Herrscher. Korrespondenz Maximilians II, Band 2: Familienkorrespondenz 1566 August 9 bis 1567 Dezember 27, [w:] Veröffentlichungen der Kommission für Neuere Geschichte Österreichs, Band 16, bearb. von V. Bibl, Wien 1921, s. 65-69.

38 Ferdinand an Maximilian aus Rokitzan, 4. Jänner 1567, ibidem, Band 2, s. 76-77.
} 
było, aby być pochowaną w Pradze u stóp matki, Anny Jagiellonki ${ }^{39}$. Z perspektywy Zygmunta Augusta jej śmierć otwierała mu drogę do ponownego ożenku. Zastanawiano się nawet nad wyborem kolejnej małżonki. Ze względu na stale pogarszający się stan zdrowia króla, te plany nigdy nie zostały zrealizowane, ponieważ umiera on 7 lipca 1572 roku w Knyszynie ${ }^{40}$.

Historia Katarzyny Habsburżanki pokazuje, że nie zawsze polityka dynastyczna przynosiła pożądane skutki. Małżeństwo zawarte z Zygmuntem Augustem było porażką polityczną jej ojca oraz brata i samego króla. Należy pamiętać, że w cieniu wielkiej polityki rozgrywał się dramat kobiety wysłanej do obcego dla niej kraju, w którym musiała wypełniać przeznaczone jej zadania. Niektóre z nich, takie jak wydanie na świat potomka, okazały się niemożliwe.

Dwie młodsze arcyksiężniczki zostały wydane za mąż do krajów włoskich. Starsza z nich, Barbara urodziła się w 1539 roku w Innsbrucku. Joanna przyszła na świat w roku 1547 w Wiedniu i była najmłodszym dzieckiem Ferdynanda i Anny Jagiellonki. Obie zawarły związki małżeńskie w tym samym czasie. Barbara poślubiła Alfonsa II d'Este 5 grudnia 1565 roku, a dziesięć dni później Joanna została żoną Franciszka de Medici ${ }^{41}$.

Przyczyny natury politycznej były głównym powodem zawarcia obu małżeństw. W tamtym okresie Półwysep Apeniński był mozaiką małych państewek, gdzie ścierały się interesy monarchii Habsburgów oraz Francji. Władcy w krajach włoskich walczyli między sobą o dominację w tym regionie. Tak samo było w przypadku księstwa Ferrary i Toskanii. Zarówno ówcześnie panujący Alfonso d'Este, jak i Kosma de Medici starali się być w miarę samodzielnymi politykami na arenie międzynarodowej, jednak w walce o prymat we Włoszech potrzebowali silnego sojusznika. Po uwolnieniu się spod wpływów Francji, d’Este szukał zbliżenia z Habsburgami. Także Medyceuszy łączyły z nimi silne związki. Kiedy w 1561 roku ponownie rozgorzał między nimi spór o dominację, cesarz Ferdynand I zachował neutralność, unikając kłopotliwego opowiadania się po jednej ze stron ${ }^{42}$.

W 1563 roku cesarz miał jeszcze pięć niezamężnych córek. Do stanu małżeńskiego były przeznaczone tylko Barbara i Joanna. Trzy pozostałe zostały zakonnicami, co było zaakceptowane przez ich ojca ${ }^{43}$.

W styczniu 1563 roku były prowadzone tajne rokowania między cesarzem Ferdynandem i arcyksięciem Maksymilianem a kardynałem Trydentu Christo-

\footnotetext{
39 J. Szujski, op. cit., s. 294-295.

40 S. Cynarski, op. cit., s. 203.

41 R. Reifenscheid, op. cit., s. 132-133.

42 B. Grohs, Italienische Hochzeiten. Die Vermählung der Erzherzoginnen Barbara und Johanna von Habsburg im Jahre 1565, „Mitteilungen des Instituts für österreichische Geschichtsforschung” (MIÖG), Bd. 96/3-4 (1988), s. 331-333.
}

43 Ibidem, s. 335. 
fem Madruzzo, a w maju tego samego roku posłowie ferraryjscy utrzymywali, że sprawa małżeństwa Alfonsa powinna zostać zakończona już w maju. W tym samym czasie starania o rękę cesarskiej córki podjęli Medyceusze. Ogólnie o stanie pertraktacji małżeńskich był informowany także Filip II. Cesarz Ferdynand w memoriale do posła hiszpańskiego wyraźnie dawał do zrozumienia, iż król powinien pozostawić im w tych rokowaniach wolną rękę. Dotyczyło to także stanu rzeczy na Półwyspie Apenińskim ${ }^{44}$.

Obaj kandydaci na cesarskich zięciów bardzo różnili się od siebie. Alfons d'Este był człowiekiem energicznym, mającym szerokie zainteresowania, poczynając od chemii, a kończąc na literaturze i sztuce. Barbara Habsburżanka miała być jego drugą żoną, od której oczekiwał przede wszystkim wydania na świat potomka. Jego pierwsza małżonka Lukrecja de Medici mu go nie dała ${ }^{45}$.

Franciszek był w pewnym sensie jego przeciwieństwem. Także diametralnie różnił się od swojego ojca. Nie odziedziczył jego zalet, jakimi były pracowitość, a także przedsiębiorczość. Miał opinię człowieka kochliwego, co zapewne wiązało się z jego licznymi romansami ${ }^{46}$. O zaletach lub ewentualnych wadach kandydatów na małżonków, arcyksiężniczki zapewne mało wiedziały w tamtym okresie, ponieważ był to dopiero początek starań o ich rękę.

Po dość intensywnej wymianie poselstw w roku 1563 nastąpiło pewne wyhamowanie rokowań małżeńskich. Przyczynami tego stanu rzeczy były przede wszystkim perturbacje na Węgrzech, a także sprawa związana z Janem Zygmuntem Zapolyą, któremu była obiecana arcyksiężniczka Joanna. Innym powodem opóźnień w pertraktacjach był pogarszający się stan zdrowia cesarza, który nie doczekał finału rokowań, ponieważ zmarł w połowie 1564 roku $^{47}$. W świetle korespondencji braci: Maksymiliana II i arcyksięcia Ferdynanda, synów cesarza Ferdynanda I widzimy, iż 23 października 1564 roku pojawia się list cesarza skierowany do arcyksięcia, w którym prosi go o zgodę na małżeństwo Joanny z Franciszkiem, aby móc uzgodnić tę sprawę z posłami florenckimi, którzy są już zniecierpliwieni ${ }^{48}$. Z kolejnego listu do Ferdynanda, brata Joanny, dowiadujemy się, iż ten ostatni wyraził zgodę na to małżeństwo i aby dopełnić formalności potrzebna jest jeszcze zgoda arcyksiężniczki Joanny ${ }^{49}$.

Nie odnajdujemy w listach między braćmi informacji dotyczących Barbary. Na podstawie tych dwóch listów można wywnioskować, iż zgoda Joanny, o której pisze cesarz, jest w zasadzie najmniej ważna. Świadczy o tym twierdzenie,

\footnotetext{
44 Ibidem, s. 335-336.

45 K. Chłędowski, Dwór w Ferrarze, Lwów 1930, s. 311-313.

46 C. Hibbert, Medyceusze: wzlot i upadek, Łódź 1992, s. 267.

47 B. Grohs, op. cit., s. 337-338.

48 Maximilan an Ferdinand aus Wien, 23. Oktober 1564, ibidem, Band 1, s. 55-56.

49 Maximilian an Ferdinand aus Wien, 30-31. Oktober 1564, ibidem, Band 1, s. 57-60.
} 
że jest to tylko formalność, ponieważ wiadomo było, że Habsburżanka nie zniweczy planów politycznych rozpoczętych jeszcze przez jej ojca. Decyzję Habsburgów o zawarciu tych dwóch małżeństw ułatwiły przede wszystkim korzyści finansowe, jakie mogli uzyskać, a zbliżająca się wojna z Turcją wiązała się $\mathrm{z}$ wielkim nakładem pieniężnym. Traktaty małżeńskie z księstwem Ferrary zostały podpisane 16 października 1564 roku, a z Medyceuszami dopiero 4 marca roku następnego ${ }^{50}$.

Chcąc poznać swoją małżonkę, Alfonso d'Este przybył 28 lipca do Innsbrucka. W przeciwieństwie do braci, którzy od małego uczyli się języków obcych, arcyksiężniczki znały tylko łacinę, co w przypadku Barbary i Joanny stanowiło pewną trudność w komunikowaniu się z przyszłymi małżonkami. Przybywając do Austrii książę Ferrary przywiózł swojej narzeczonej podarunki, składające się z różnego rodzaju kosztowności. Cały jego pobyt w stolicy Tyrolu był dokładnie zaplanowany. Wziął udział we mszy świętej, spędzał czas z arcyksiężniczkami. Następnie udał się do Wiednia, by uczestniczyć w nabożeństwach żałobnych za zmarłego cesarza Ferdynanda. Podobnie jak w Innsbrucku, także i w Wiedniu książę Ferrary został przyjęty z wszelkimi honorami. Ponoć sam cesarz wyjechał przed bramy miasta, by móc go powitać51. W bazie źródłowej, wśród listów Maksymiliana i Ferdynanda nie odnajdujemy informacji na temat Alfonsa i jego podróży do Austrii. Sposób podejmowania gości, jaki został wyżej zaprezentowany był naturalną procedurą. Jako przyszłego szwagra, a przede wszystkim sojusznika, cesarz musiał podejmować Alfonsa d'Este z wszelkimi honorami i rozmachem, zapewne przy tym nie oszczędzając.

Na podobną podróż zdecydował się drugi z przyszłych szwagrów cesarza, Franciszek de Medici. Tak jak poprzednika, celem jego podróży był przede wszystkim Innsbruck, gdzie przebywały arcyksiężniczki. Należy przy tym zauważyć, że toskański książę dużo później znalazł się w stolicy Tyrolu. Najpierw przybył do Wiednia, gdzie pojawił się pod koniec października. W listach między cesarzem a arcyksięciem Ferdynandem pojawia się wzmianka na temat wizyty młodego Medyceusza. Chodziło przede wszystkim o sposób podejmowania gościa, a także o trasę jego podróży przez kraje habsburskie. Jej koszta miały być na razie złożone na barkach Kaspara Liechtenberga, z którym potem należało się rozliczyć i zwrócić mu wyłożone przez niego pieniądze. Cesarz wyznaczył także dwie osoby, który miały służyć księciu podczas jego przejazdu do Pragi. $\mathrm{Na}$ podstawie tego listu trasa podróży Franciszka zarysowuje się następująco: z Pragi książę miał udać się do Linzu, a stamtąd miał być doprowadzony do Salzburga. Dalej jego droga prowadziła do Tyrolu i zarząd nad jego pobytem tam cesarz oddaje arcyksięciu Ferdynandowi. Oczywiście zaleca, by Medyceusz

50 B. Grohs, op. cit., s. 339.

51 Ibidem, s. 340-341. 
nadal był traktowany z wszelkimi honorami i aby niczego mu nie brakowało ${ }^{52}$. Tak samo jak Alfonso d'Este, po dotarciu do Innsbrucka, Franciszek obdarował swoją przyszłą małżonkę kosztownymi podarunkami ${ }^{53}$.

W drugiej połowie 1565 roku między Maksymilianem II a Ferdynandem Tyrolskim następuje intensywniejsza wymiana korespondencji na temat arcyksiężniczek Barbary i Joanny. W liście z 20 lipca cesarz podejmuje problem uposażenia sióstr. Kwestia ta nie była jedynie sprawą wewnętrzną rodziny. Taka rzecz, jak posag przyszłych żon miała przejść przez rząd górnoaustriacki. Również zamówienia na takie materiały, jak jedwab czy aksamit miały być odprawione przez administrację. W wianie sióstr przewidziane były też klejnoty, które miały pochłonąć spore sumy pieniędzy. Cesarz poinformował, że będą one przesłane przez niego i arcyksięcia Karola ${ }^{54}$. Według założeń braci, siostry miały dotrzeć do Trydentu 15 listopada 1565 roku. Tam powinny być przyjęte przez przyszłych małżonków i udać się z nimi do Ferrary i Florencji ${ }^{55}$. Ze względu na przedłużający się pobyt księcia Toskanii w Wiedniu, terminy te uległy zmianie. Według dekretu rządu górnoaustriackiego miały one wyruszyć z Innsbrucka 15 listopada, a w Trydencie pojawić się 20 listopada $^{56}$.

$\mathrm{W}$ dalszej korespondencji z października pojawia się problem finansowy, z którym zresztą Habsburgowie bardzo często musieli się zmagać. Ferdynand donosi, iż rząd górnoaustriacki domaga się uiszczenia 37,5 tysiąca guldenów, które miały być udziałem Maksymiliana i arcyksięcia Karola w finansowaniu podróży sióstr do Trydentu. Dodatkowo nie zostały przekazane pewne sumy pieniędzy na utrzymanie dworu arcyksiężniczek. Przy tym, w przypisach do listu możemy wyczytać, że całą ich wyprawę Ferdynand wycenił aż na 120 tysięcy guldenów ${ }^{57}$. Przy tych trudnościach finansowych, jakie posiadali Habsburgowie, suma ta była ogromna, tym bardziej, że cały czas potrzebne były środki na kampanię przeciwko Turcji. W odpowiedzi na pismo brata, cesarz przeprowadza kalkulację. Z 37,5 tys. guldenów wkładu w utrzymanie sióstr i ich podróż, 25 tys. miał dostarczyć Maksymilian, resztę zaś Karol. Dodatkowe 15 tys. zostało wysłane przez Georga Ilsunga (prawdopodobnie bankiera), a najmłodszy z arcyksiążąt zamierzał uzyskać jeszcze 7,5 tys. Według obliczeń cesarza, wraz z wkładem Ferdynanda dawało to w sumie 80 tys. guldenów. Maksymilian uważał tę kwotę za wysoką, za którą można byłoby już pokryć wiele kosztów. Dalej można się dowiedzieć, iż nie tylko Barbara i Joanna wymagały sporych nakładów finansowych, lecz także

\footnotetext{
52 Maximilian an Ferdinand aus Wien, 3. November 1565, Band 1, s. 299-300.

53 B. Grohs, op. cit., s. 342.

54 Maximilian an Ferdinand aus Wien, 20. Juli 1565, Band 1, s. 213-214.

55 Maximilian an Ferdinand aus Wien, 24. August 1565, ibidem, Band 1, s. 253-254.

56 Maximilian an Ferdinand aus Wien, 4. November 1565, ibidem, Band 1, s. 300.

57 Ferdinand an Maximilian aus Prag, 3. Oktober 1565, ibidem, Band 1, s. 272.
} 
trzy pozostałe niezamężne siostry ${ }^{58}$. Wydaje się, że można śmiało stwierdzić, iż brak pieniędzy to była jedna z największych bolączek Habsburgów. Korzystne wydanie sióstr za mąż wiązało się z przydatnymi sojuszami, a także z pomocą finansową, na którą cesarz liczył. Aby jednak to wszystko osiągnąć, sami musieli się zdobyć na ogromny wysiłek finansowy. Wielokrotne konsultacje i narady na pewno rozstrzygały o tym, iż warto włożyć w to taki trud. Polityczne efekty tych związków miały owocować w przyszłości.

Małżeństwa zawarte przez obie arcyksiężniczki były przede wszystkim umowami politycznymi. Po wystawnych uroczystościach weselnych musiały się odnaleźć w zupełnie nowej rzeczywistości i podołać stawianym im zadaniom. Ich związki małżeńskie, tak jak w wypadku starszej siostry Katarzyny, nie były szczęśliwe. Alfons d'Este dość szybko pozostawił swoją młodą żonę, udając się jako sojusznik Habsburgów na kampanię wojenną na Węgry. W jeszcze trudniejszej sytuacji była Joanna, która o względy męża musiała rywalizować z jego kochanką, Biancą Capello ${ }^{59}$. Habsburżanka urodziła Franciszkowi syna, lecz rok później zmarła, a niedługo po niej także ich $\operatorname{syn}^{60}$.

Po śmierci cesarza Ferdynanda I losy jego córek były trudne i dość dramatyczne. Trzy zostały wydane za mąż, ale ich małżeństwa okazały się nieszczęśliwe. Korespondencja Maksymiliana II i Ferdynanda Tyrolskiego pokazuje m.in., jak wyglądała opieka, jaką bracia musieli sprawować nad siostrami. W przypadku najstarszej z nich, Katarzyny, było to przede wszystkim niedopuszczenie do rozpadu jej małżeństwa z królem polskim Zygmuntem Augustem. Starania podejmowane przez braci, jak się później okazało, nie przyniosły rezultatów, a arcyksiężniczka ostatecznie wyjechała z Rzeczypospolitej w 1568 roku. $\mathrm{Z}$ perspektywy polityki dynastycznej Jagiellonów było to bardzo niekorzystne, ponieważ tracili oni możliwość następstwa na tronie polskim. Małżeństwo Katarzyny i Zygmunta Augusta było kolejną, nieudaną próbą porozumienia między dynastią habsburską a jagiellońską.

Po powrocie Katarzyny do Austrii na Maksymiliana, Ferdynanda i Karola spadał obowiązek opieki nad siostrą i zapewnienia jej godziwych warunków życia.

Trochę inaczej przedstawiała się sytuacja dwóch młodszych sióstr, Barbary i Joanny. Po śmierci ojca bracia musieli zaopiekować się siostrami i doprowadzić do sfinalizowania rozpoczętych jeszcze przez Ferdynanda I pertraktacji małżeńskich z władcami Ferrary i Toskanii. W korespondencji Maksymiliana i Ferdynanda Tyrolskiego poruszane były m.in. sprawy finansowe, dotyczące uposażenia sióstr, a także te, które były związane z ich podróżą do Ferrary i Flo-

\footnotetext{
58 Maximilian an Ferdinand aus Wien, 5. Oktober 1565, ibidem, Band 1, s. 272-273.

59 B. Grohs, op. cit., s. 381.

60 C. Hibbert, op. cit., s. 267.
} 
rencji. Należy pamiętać, że zbiegało się to w czasie z narastającym konfliktem na Węgrzech, więc jakiekolwiek dodatkowe koszta musiały być przez braci dokładnie konsultowane. Wydaje się jednak, że było to traktowane jako inwestycja na przyszłość, ponieważ oczekiwano od przyszłych małżonków Barbary i Joanny udzielenia pomocy podczas wojny na Węgrzech.

Korespondencja Maksymiliana II i Ferdynanda Tyrolskiego z lat 1564-1567 pozwala spojrzeć na jeden z elementów spraw rodzinnych, jakim była opieka nad siostrami. Pozwala ona także na przynajmniej częściowe poznanie tego, jak potoczyły się ich losy po śmierci ojca. Małżeństwa arcyksiężniczek były elementem polityki zagranicznej Habsburgów. W trzech opisywanych przypadkach były to przede wszystkim umowy, które w swym założeniu miały przynosić korzyści głównie dynastii Habsburgów. Wymiana listów między cesarzem Maksymilianem a arcyksięciem Ferdynandem pozwala spojrzeć na ten problem od środka, z perspektywy członków rodziny cesarskiej.

\section{The fate of Habsburg sisters: Katarzyna, Barbara and Joanna after the death of their father Ferdinand I, Holy Roman Emperor, in the light of the family correspondence}

Daughters of the Habsburgs, fulfilling the dynastic policy of the family, married European rulers. The aim was to enter into profitable alliances or gain prospective financial aid.

In 1553 Katarzyna Habsburżanka (Catherine of Austria) married Zygmunt August (Sigismund II Augustus). It was not a happy marriage. Katarzyna was not able to give her husband a much awaited son, thus, form the end of the 1550s their married life showed signs of falling apart. In 1559 the issue of the king's divorce appeared for the first time. Despite intense exchange of legation between the Polish king and Maximillian II, Holy Roman Emperor, Katarzyna left the Crown in October 1566. However, Zygmunt August did not get a divorce and, thus, lost a chance to have a legal descendant.

Archduchesses Barbara (Barbara of Austria) and Joanna (Joanna of Austria) were married to the rulers on the Apennine Peninsula. The first one became the wife of Alfonso II d'Este, Duke of Ferrara, Joanna was the wife of Francesco I de'Medici, Grand Duke of Tuscany. Both these marriages constituted a kind of agreement: Italian dukes counted on a powerful ally in the struggle for domination of the Apennine Peninsula; the Habsburgs expected mainly financial and military help in the campaign against Turkey.

Marriages of Barbara and Joanna, like that of their sister Katarzyna, were not totally happy, although they did not end in separation. The fates of the Habsburg sisters clearly show that marriages concluded between members of the reigning houses not always fulfilled the expectations of the involved parties. 
Key words: the Habsburgs, Maximillian II, Holy Roman Emperor, correspondence, marriages of members of the reigning houses, Sigismund II Augustus

\section{Bibliografia}

\section{Źródła}

Bielski M., Kronika Polska, Warszawa 1764.

Górnicki Ł., Dzieje w Koronie Polskiej, Wrocław 1950.

Korrespondenzen österreichischer Herrscher. Korrespondenz Maximilians II. Familienkorrespondenz 1564 Juli 26 bis 1566 August 11, herausgegeben von Victor Bibl, Bd. 1, Wien, Holzhausen 1916.

Korrespondenzen österreichischer Herrscher. Korrespondenz Maximilians II. Familienkorrespondenz 1566 August 9 bis 1567 Dezember 27, herausgegeben von Victor Bibl, Bd. 2, Wien, Holzhausen 1921.

\section{Opracowania}

Besala J., Stefan Batory, Warszawa 1992.

Borkowska U., Dynastia Jagiellonów w Polsce, Warszawa 2011.

Chłędowski K., Dwór w Ferrarze, Lwów 1930.

Cynarski S., Zygmunt August, Wrocław 1988.

Gołębiowski S., Czasy Zygmunta Augusta. Ustęp z przeszłości, cz. 1, Wilno 1851.

Grodziski S., Habsburgowie. Dzieje dynastii, Wrocław 1998.

Grohs B., Italienische Hochzeiten. Die Vermählung der Erzherzoginnen Barbara und Johanna von Habsburg im Jahre 1565, „Mitteilungen des Instituts für Österreichische Geschichte (MIÖG), Bd. 96/3-4 (1988).

Hibbert C., Medyceusze: wzlot i upadek, Łódź 1992.

Przeździecki A., Jagiellonki polskie. Obrazy dworu Zygmunta I i Zygmunta Augusta Królów Polskich, t. 2, Kraków 1868.

Reifenscheid R., Die Habsburger. Von Rudolf I. bis Karl I., Wien 1994.

Sucheni-Grabowska A., Zygmunt August. Król Polski i wielki ksiąze litewski 1520-1562, Kraków 2010.

Szujski J., Opowiadania i roztrzqsania, t. 2, Kraków 1886.

Żelewski R., Katarzyna Austriaczka, [w:] Polski Stownik Biograficzny, t. 12, 1990, s. 214-216. 